\title{
STOCK MARKET PRICE AND ITS DETERMINANTS: A CASE STUDY OF NIGERIAN BANKS
}

\author{
Onyedikachi O. John ${ }^{1 *}$ \\ *1Department of Physical Sciences, Rhema University, Nigeria, johnkady@yahoo.com
}

*Corresponding Author: -

Email: johnkady@yahoo.com

\begin{abstract}
: -
Financial firms in a country make a substantial fraction of its equity market. The present study is aimed at examining the factors that influence stock prices with reference to Nigerian banks. Twelve commercial banks in Nigeria are considered for this study for 2012 and 2013. Using linear regression model and partial correlation, the results indicate that for both years considered, net asset value per share and price-book value ratio are strongly correlated with stock market price, and are having significant influence on the stock price. However, dividend per share and price-earnings ratio are significant in 2013, but insignificant in 2012.
\end{abstract}

Keywords: - Stock Market Price, Net Asset Value per Share, Price-Earnings Ratio, Price-Book Value Ratio, Dividend per Share, Partial Correlation 


\section{I.INTRODUCTION}

Financial firms in a country make up a substantial fraction of its equity market. The capital market which includes stock market and bond market plays vital role in economic prosperity that fosters capital formation and sustains economic growth. According to Kurihara [14], stock markets are essential for economic growth as they ensure the flow of resources to the most productive investment opportunities. A stock price in an efficient market provides investors with a good measure of any firm's performance and its value.

However, given the dynamics of the stock market, investors have always been confronted with the problem of predicting stock prices so as to earn decent returns. Understanding the impact of various fundamental variables on stock price is very much helpful to investors as it will help them in taking profitable investment decision, Srinivasan [20]. It is of interest to know that many factors both intrinsic and extrinsic influence the movement of stock prices, and identifying them is of great importance to investors.

This study is aimed at identifying the factors affecting stock market prices of banks in Nigeria, and also to investigate the relationship between stock prices of these banks and the predictor variables.

\section{Literature Review}

A number of studies have been done to investigate the factors influencing stock prices and also to know the possibility of predicting future returns with good precision.

De Bondt and Thaler [6], Jegadeesh and Titman [13], Chopra, Lakonishok and Ritter [4], and Jegadeesh [12], show that the history of a stock is useful in predicting relative returns. Fema and French [9], Lakonishok, Shleifer and Vishny [15], and Davis [5], show that future returns can be predicted by the relative sizes of the current values of accounting numbers, such as book value or earnings per share.

Levine and Zervos [16], find that various measures of stock market activity are positively correlated with measures of real economic growth across countries, and that the association is particularly strong for developing countries. Their results also show that after controlling for initial conditions and economic and political factors, the measures of banking and stock market development are robustly correlated with current and future rates of economic growth and productivity improvement. Docking and Koch [7] discovers that there is a direct relationship between dividend announcement and equity price behavior.

Malhotra and Tandron [17], attempted to determine the factors that influence stock prices in the context of NSE of 100 companies. The results indicated that the firm's book value, earning per share, and price-earnings ratio have significant positive association with firm's stock price, while dividend yield have a significant inverse association with the market price of firm's stock.

Fisher [10], showed the impact of dividends, undistributed profits, and company size on share prices taken from five cross sectional samples of equities quoted on the London stock exchange between 1949 and 1957. Uddin [22], found a significant linear relationship between market returns and such factors as net asset value per share, dividend percentage, earnings per share of bank leasing and insurance companies.

Almumani [1], attempted to identify the quantitative factors that influence share prices for listed banks in Amma Stock Exchange over the period 2005 - 2011. The results showed the earnings per share, price - earnings ratio, book value and size to have significant impact on stock market price, while dividend per share and dividend payout ratio are insignificant.

Al-Shubiri [2], investigated the relationship between stock price and microeconomic factors in 14 commercial banks of Amman Stock Exchange, and found high positive significant relationship between price of stock and net asset value per share, dividend percentage, gross domestic product and a negative significant relationship on inflation and lending interest.

Sharma [18], examined the empirical relationship between equity share prices and book value per share, dividend per share, price-earnings ratio, dividend yield, dividend payout, size in terms of sale, and net worth. The results showed that earnings per share, dividend per share, book value per share have significant impact on market price of share.

Collins [3], identified dividend, net profit, operating earnings and book value as the factors influencing share prices for United States banks. According to Geetha and Swaaminathan [11], Book value, earnings per share and price-earnings ratio show a significant effect on market price of share, while dividend per share is insignificant.

Wilcox [24], Rappaport [21], Downs [8], Sharma and Singh [19], Sharma [18] suggest that share price changes are associated with changes in fundamental variables that are relevant for share valuation like book value per share, dividend coverage ratio, dividend per share, earnings per share, dividend payout ratio, price-earnings ratio and firm size.

\section{III.Methodology}

\section{A. Linear regression}

Consider a data with n observations of a response $y_{i}$, and a set of independent variables (predictors),

$$
x_{i}^{T}=\left(x_{i 0}, x_{i 1_{1}, \ldots,} x_{i p}\right)
$$

The response variable is a function of the regressors,

$$
y_{i}=x_{i}^{T} \beta+\epsilon_{i}
$$


This model can be expressed in matrix notation,

$$
y=X \beta+\epsilon
$$

where y and e are nx1 vectors, and $X$ is the design matrix. The $\hat{\beta}$, can be obtained by solving

$$
\hat{\beta}=\left(X^{T} X\right)^{-1} X^{T} y
$$

\section{B. Partial correlation}

According to Younger [23], the order of the partial correlation is the number of the controlled variables. Simple bivariate unconditional correlations are referred to as zero-order correlations. Third-order partial correlation between $\mathrm{x} 1$ and $\mathrm{y}$ controlling for $\mathrm{x} 2, \mathrm{x} 3$ and $\mathrm{x} 4$ is given by

$$
r_{1 y .234}=\frac{r_{1 y .23}-\left(r_{14.23}\right)\left(r_{4 y .23}\right)}{\sqrt{1-r_{14.23}^{2}} \sqrt{1-r_{4 y .23}^{2}}}
$$

$R^{2}$,which is the coefficient of determination is computed to determine the percentage of variation in the

$$
R^{2}=1-\frac{S S(E)}{S S(T)}
$$

dependent variable explained by the independent variables. The F-value is computed to test the significance of $R^{2}$ with F- distribution at $5 \%$ level of significance.

The hypotheses are as follows:

$\mathrm{H}_{0}$ : There is no significant relationship between the dependent variable (stock price) and the independent variables (dividend per share, net asset value per share, price-earnings ratio and price-book value ratio)

H1: There is a significant relationship between the dependent variable (stock price) and the independent variables (dividend per share, net asset value per share, price-earnings ratio and price-book value ratio)

\section{IV.Analysis And Discussion}

Twelve commercial banks in Nigeria namely, Access bank, Diamond bank, First City Monument bank, Fidelity bank, Guaranty Trust bank, Skye bank, Stanbic IBTC, Sterling bank, United Bank for Africa, Zenith bank, First Bank of Nigeria, and Wema Bank, have been analyzed with stock market price (smp) as dependent variable, and dividend per share (dps), net asset value per share (navs), price-earnings ratio (pe) and price-book value ratio (pb) as the independent variables. The results are presented below:

Table I: correlation 2012

\begin{tabular}{|c|c|c|c|c|c|}
\hline & SMP & NAVS & PE & PB & DPS \\
\hline SMP & 1 & 0.794 & 0.372 & 0.914 & 0.839 \\
\hline NAVS & & 1 & 0.258 & 0.517 & 0.772 \\
\hline PE & & & 1 & 0.436 & -0.009 \\
\hline PB & & & & 1 & 0.661 \\
\hline DPS & & & & & 1 \\
\hline
\end{tabular}

Table II: Partial correlation 2012

\begin{tabular}{|c|c|c|c|c|}
\hline \multirow{2}{*}{ Control variables } & \multicolumn{4}{|c|}{ SMP } \\
\cline { 2 - 5 } & DPS & NAVS & PE & PB \\
\hline PE \& PB \&DPS & & 0.820 & & \\
\hline PE \& PB \& NAVS & 0.469 & & & \\
\hline PE \& NAVS \& DPS & & & & 0.939 \\
\hline NAVS \& DPS \& PB & & & 0.070 & \\
\hline
\end{tabular}


Table III: Linear regression result 2012

\begin{tabular}{|c|c|c|c|c|}
\hline model & Coefficients & Standard error & $\mathrm{t}$ & sig \\
\hline constant & -5.536 & 1.047 & -5.289 & 0.001 \\
\hline navs & 0.661 & 0.175 & 3.784 & 0.007 \\
\hline $\mathrm{pe}$ & 0.019 & 0.100 & 0.185 & 0.858 \\
\hline $\mathrm{pb}$ & 7.973 & 1.106 & 7.212 & 0.000 \\
\hline $\mathrm{dps}$ & 2.397 & 1.707 & 1.404 & 0.203 \\
\hline \multicolumn{5}{|c|}{ R-square $=0.983$} \\
Standard Error of Estimate $=1.21410 \mathrm{~F}=99.168, \mathrm{p}$-value $=0.000$ \\
\hline
\end{tabular}

Table I shows that the stock market price has strong positive correlation with net asset value per share, price-book value ratio and dividend per share, but weak positive relationship with price-earnings ratio. Dividend per share is also correlated with net asset value per share and price-book value ratio.

In table II, with price-earnings ratio, price-book value ratio and dividend per share controlled, the partial correlation of stock market price and net asset value per share is 0.820 . This implies that net asset value per share explains $67.24 \%$ of the variation in the stock market price that is left unexplained by the price-earnings ratio, price-book value ratio and dividend per share. This indicates that net asset value per share is a significant predictor of stock price. With priceearnings ratio, net asset value per share and dividend per share controlled, the partial correlation of stock price and price-book value ratio is 0.939 , implying that the price-book value ratio explains $88.17 \%$ of the variation in the stock market price which is left unexplained by price-earnings ratio, net asset value per share and dividend per share. This also indicates that price-book value ratio is a significant predictor of stock market price. However, with price-earnings ratio, price-book value ratio and net asset value per share controlled, the partial correlation of stock market price and dividend per share is 0.469 , implying that dividend per share explains only $22 \%$ of the variation in the stock price that is left unexplained by price-earnings ratio, price-book value ratio and net asset value per share. This indicates that dividend per share is not significant. In the same vein, price-earnings ratio explains only $0.49 \%$ of the variation in market price that is left unexplained by price-book value ratio, dividend per share and net asset value per share, indicating that price-earnings ratio is not significant. The foregoing agrees with the t-test (see table III) which judges net asset value per share and price-book value ratio significant, and dividend per share, price-earnings ratio non significant variables.

In table III, the coefficient of determination $\mathrm{R}^{2}=0.973$, indicates that the model is good. And F-statistic which is 99.168 with p-value of 0.000 proves the validity of the estimated model.

Table IV: Correlation 2013

\begin{tabular}{|c|c|c|c|c|c|}
\hline & SMP & NAVS & PE & PB & DPS \\
\hline SMP & 1 & 0.784 & 0.166 & 0.904 & 0.961 \\
\hline NAVS & & 1 & -0.188 & 0.480 & 0.798 \\
\hline PE & & & 1 & 0.243 & 0.087 \\
\hline PB & & & & 1 & 0.808 \\
\hline DPS & & & & & 1 \\
\hline
\end{tabular}

Table V: Partial correlation 2013

\begin{tabular}{|c|c|c|c|c|}
\hline \multirow{2}{*}{ Control variables } & \multicolumn{4}{|c|}{ SMP } \\
\cline { 2 - 5 } & DPS & NAVS & PE & PB \\
\hline PE \& PB \&DPS & & 0.944 & & \\
\hline PE \& PB \& NAVS & 0.892 & & & \\
\hline PE \& NAVS \& DPS & & & & 0.975 \\
\hline NAVS \& DPS \& PB & & & 0.796 & \\
\hline
\end{tabular}

Table VI: Linear regression result 2013

\begin{tabular}{|c|c|c|c|c|}
\hline model & Coefficients & Standard error & $\mathrm{t}$ & $\mathrm{sig}$ \\
\hline constant & -7.657 & 0.934 & -8.199 & 0.000 \\
\hline navs & 0.719 & 0.095 & 7.563 & 0.000 \\
\hline $\mathrm{pe}$ & 0.225 & 0.064 & 3.485 & 0.010 \\
\hline $\mathrm{pb}$ & 6.741 & 0.579 & 11.645 & 0.000 \\
\hline $\mathrm{dps}$ & 4.928 & 0.945 & 5.217 & 0.001 \\
\hline \multicolumn{5}{|c|}{ R-square $=0.997$} \\
Standard Error of Estimate $=0.65477 \mathrm{~F}=550.166, \mathrm{p}$-value $=0.000$ \\
\hline
\end{tabular}


Table IV shows that the stock market price has strong positive correlation with net asset value per share, price-book value ratio and dividend per share, but very weak positive correlation with price-earnings ratio. Dividend per share also has strong positive correlation with net asset value per share and price-book value ratio.

In table $\mathrm{V}$, the partial correlation of stock market price and net asset value per share with price-earnings ratio, pricebook value ratio and dividend per share controlled is 0.944 . This implies that net asset value per share explains $89.11 \%$ variation in the stock market price that is left unexplained by price-earnings ratio, price-book value ratio and dividend per share, indicating that net asset value per share is significant. With price-earnings ratio, price-book value ratio and net asset value per share controlled, the partial correlation of stock price and dividend per share is 0.892 , implying that dividend per share explains $79.57 \%$ of the variation in stock price that is left unexplained by price-earnings ratio, pricebook value ratio and net asset value per share. This indicates that dividend per share is significant. With price-earnings ratio, net asset value per share and dividend per share controlled, the partial correlation of stock market price and price-book value ratio is 0.975 , implying that price-book value ratio explains $95.06 \%$ of the variation in the stock price that is left unexplained by price-earnings ratio, net asset value per share and dividend per share. This indicates pricebook value ratio is a significant predictor of stock price. With net asset value per share, dividend per share and pricebook value ratio controlled, the partial correlation of stock price and price-earnings is 0.796 , implying that priceearnings ratio explains $63.36 \%$ of the variation in stock price that is left unexplained by net asset value per share, dividend per share and price-book value ratio. This indicates that price-earnings ratio is significant. These also agree with the t-test in table VI having t-values, navs $=7.563$, pe $=3.485, \mathrm{pb}=11.645, \mathrm{dps}=5.217$, and $\mathrm{p}$-values respectively $0.000,0.010,0.000,0.001$.

In table VI, the coefficient o determination, $\mathrm{R}^{2}=0.997$ indicates that the model is very good. The F-statistic which is 550.160 with p-value 0.000 also proves the validity of the model.

\section{Conclusion}

The current study examines the influence of net asset value per share, price-earnings ratio, price-book value ratio and dividend per share on the share price of twelve commercial banks in Nigeria for two years, 2012 and 2013 . The study reveals that net asset value per share and price-book value ratio have significant influence on the stock market price in both years, while dividend per share and price-earnings ratio are significant factors in 2012, but non- significant factors in 2012. The findings of this study will help investors watch out for the significant factors while analyzing stock returns and predicting future prices.

\section{References}

[1].Almumami, Mohammad Abdelkarim, "Determinants of Equity Share Prices of Listed Banks in Amman Stock Exchange: Quantitative Approach”, International Journal of Business and Social Science, 2014, vol. 5 No. 1.

[2].Al-Shubiri, F., "Analysis of the Determinants of Market Stock Price Movements: An Emperical Study of Jordanian Commercial Banks", International Journal of Business and Management, 2010, 5(10): 137.

[3].Collins, "How to Study the Behaviour of Bank Stocks", The Analyst Journal,1957, 13(2): 109 - 113.

[4].Chopra, Navin, Josef Lakonishok and Jay Ritter, "Measuring Abnormal Performance: Do Stocks Overreact?", Journal of Financial Economics, 1992, 31, 235-268.

[5].Davis, James L., "The Cross-Section of Realized Stock Returns: The Pre-Compustat Evidence”, Journal of Finance, 1994, 49, 1579-1593.

[6].De Bondt, Werner F. M. and Richard H. Thaler, “Does the Stock Market Overreact?”, Journal of Finance, 1985, 40, 793-808.

[7].Docking, Diane S. and Koch, Paul D., "sensitivity of Investor Reaction to Market Direction and Volatility: Dividend Change Announcements, Journal of Financial Research, 2005.

[8].Downs, T. W., "An Alternative Approach to Fundamental Analysis: The Asset Side of the Equation", Journal of Portfolio Management, 1991, 17(2), 6-17.

[9].Fema, Eugene F. and Kenneth R. French, “The Cross-Section of Expected Returns”, Journal of Finance, 1992, 47, 427-465.

[10]. Fisher, G., "Some Factors Influencing Share Prices", The Economic Journal, 1961, 71(281): 121-141.

[11]. Geetha, E. and Swaaminathan,Ti. M., "A Study on the Factors Influencing Stock Price - A comparative Study of Automobile and Information Technology Industries Stocks in India", International Journal of Current Research and Academic Review, 2015, vol. 3, No. 3, pp 97-109.

[12]. Jegadeesh, Narasimhan, "Evidence of Predictable Behaviour of Security Returns", Journal of Finance, 1990, 45, 881-898.

[13]. Jegadeesh, Narasimhan and Sheridan Titman, "Returns to Buying Winners and Selling Losers", Journal of Finance, 1993, 48, 65-91.

[14]. Kurihara, U., "The Relationship between Exchange Rate and Stock Prices During the Quantitative Easing Policy in Japan”, International Journal of Business, 2006, 11(4), 375-386.

[15]. Lakonishok, Josef, Anderei Sheleifer and Robert Vishny, "Contrarian Investment, Extrapolation and Risk", Journal of Finance, 1994, 49, 1541-1578.

[16]. Levine, R. and Zervos, S., "Stock Markets, Banks and Economic Growth", American Economic Review, 1998, 88, 537-558.

[17]. Malhotra, Nidhi and Kamini Tandon, "Determinants of Stock Prices: Empirical Evidence from NSE 100 
Companies”, International Journal of Research and Management and Technology, 2013, vol. 3, No. 3.

[18]. Sharma, S., "Determinants of Equity Share Prices in India", Journal of Art, Science and Commerce, 2011, 2(4): 5160.

[19]. Sharma, S. and Singh, B., "Determinants of Equity Share Prices in Indian Corporate Sector: An Empirical Study", The ICFAI Journal of Applied Finance, 2006, 12(4), 21-38.

[20]. Srinivasan, P., "Determinants of Equity Share Prices in India: A Panel Data Approach", The Romanian Economic Journal, 2012, 46, 205- 228.

[21]. Rappaport, A., “The Affordable Dividend Approach to Equity Valuation”, Financial Analysts Journal, 1986, 42(4), $52-58$.

[22]. Uddin, M. B., "Determinants of Market Price of Stock: A Study of Bank Leasing and Insurance Companies of Bangladesh", Journal of Modern Accounting and Auditing, 2009, 5(7): 1-7.

[23]. Younger, Mary Sue, “A First Course in Linear Regression, $2^{\text {nd }}$ Edition”, Boston, U.S.A: Duxbury Press, 1985.

[24]. Wilcox, J. W., “The P/B-ROE Valuation Model”, Financial Analysts Journal, 1984, 40(1), 58-66. 